\title{
KONSERVATISMIN PALUU
}

Viime vuosien ideologista ja poliittista ilmapiiriä on niin Suomessa kuin länsimaissa laajemminkin kuvannut konservatismin paluu. Edelleen jatkuva talouden taantuma näyttää nostaneen ilmiön pinnalle. Konservatismin paluu on nähtävä myös yhtenä syynä EU:n hajaannukselle, josta kertoo esimerkiksi se, että Britanniassa mielipide, jonka mukaan kuningaskunnan tulisi erota EU:sta, on kerännyt laajaa kannatusta. Myös Suomessa enemmän tai vähemmän vakavasti otettavat "irti EU:sta" ja "markka takaisin" -diskurssit ovat viime aikoina olleet yleisiä. EU:n puolustajia löytyy meiltä niin talouseliitistä kuin liberaalista vasemmistostakin. Ensin mainitulle kyse lienee ennen kaikkea vaivalla rakennetusta talousalueesta, viimeksi mainitulle taas arvoyhteisöstä - joskin viime vuonna alkanut turvapaikanhakijakriisi on saanut monet kysymään, mitä ne eurooppalaiset arvot oikeastaan ovatkaan.

Konservatiivisuus edustaa tyypillisesti vanhoillisuutta ja jopa taantumuksellisuutta, kun taas liberaalius edustaa uudistus- ja vapaamielisyyttä. Konservatismi ja liberalismi ideologioina pakenevat silti selkeitä määritelmiä: konservatiivit vastustavat kaikkia ideologioita ja abstrakteja poliittisia opinkappaleita, jotka lupaavat jotain parempaa tai jotain enemmän kuin aiemmin. Konservatiivi vaalii olemassa olevaa suhtautuen muutokseen varovaisesti (Luoma-Aho 2012, 52).

Suomalaisessa politiikassa konservatiivisuus yhdistetään perinteisyyteen ja taantumuksellisuuteen, kun politiikassa yleensä tavoitellaan mieluummin muutoksen mielikuvaa. Niin \& näin -lehden "konservatismi \& liberalismi" -teemanumerossa (4/2012) kyseltiin johtavilta poliitikoilta, mitä merkitystä konservatismi-liberalismi-jaottelulla on Suomen tai poliitikon edustaman puolueen politiikassa. Arvoliberalismia kertoivat kyselyssä kannattavansa kokoomuksen Alexander Stubb, vihreiden Ville Niinistö ja vasemmistoliiton Paavo Arhinmäki. Sen sijaan arvokonservatiiviksi ei luokitellut itseään kuin kristillisdemokraattien Päivi Räsänen. Perussuomalaisten Timo Soini ei vastannut kyselyyn mutta on omissa blogikirjoituksissaan kannattanut konservatismia (Syrjämäki 2012, 20-22). Vastaukset heijastavat länsimaisen kulttuurin yleistä asenneilmapiiriä, sillä länsimaissa ihmiset määrittelevät itsensä mieluummin liberaaleiksi kuin konservatiiveiksi. Yhdysvallat poikkeaa linjasta, tosin sielläkin muutos alkoi vasta 1960-luvulla; siihen asti amerikkalaisessa mielenmaisemassa Eurooppa oli vanhoillinen ja Yhdysvallat uusi ja dynaaminen manner. Uudet neo-suuntaukset uuskonservatismi ja uusliberalismi ovat sekoittaneet aatteellista perintöä. Vesa Vares tiivistää suuntausten eron siihen, että uusliberalismi keskittyy yksilöön ja talouteen, kun taas uuskon- 
servatismi kiinnittyy enemmän moraalisiin arvoihin ja usein myös uskontoon (Vares 2012, 24-25, 32-33).

Uuskonservatismia ja uusliberalismia yhdistää kuitenkin moni asia, ja yleisessä keskustelussa niitä käytetään välillä jopa synonyymeina. Talousdiskurssin ja markkinatalouden sääntöjen läsnäolo kaikkialla ovat molempien ideologioiden esiin nostamien agendojen seurausta. Vaikka molemmat suuntaukset kannattavat markkinataloutta, niiden suhde muutokseen ja yksilöön eroaa toisistaan: konservatiivisuushan painottaa muutosvastaisuutta, kun taas uusliberalismi etsii muutosta. Ero näkyy esimerkiksi siinä, että uusliberalismissa kannatetaan ammattijärjestöjen vaikutusvallan (radikaalia) kaventamista. Suomessa kolmikannasta kiinnipitäminen on suurelle osalle suomalaisista sekä heidän työsuhde-etujensa mukaista että myös konservatiivisuutta, pitkään olleesta kiinni pitämistä - luotettavaa vaihtoehtoista mallia ei ole olemassa. Konservatiivisuus onkin ambivalentti tai jopa ristiriitainen termi, jossa talous ja politiikka (potentiaalisesti nopeasti muuttuvina) sekä arvot (yleensä hitaasti muuttuvina) ovat läsnä yhtä aikaa.

\section{Politiikka televisioviihteessä}

Televisio on ollut tärkeä areena yhteiskunnallisten muutosten käsittelyssä. Julkisen palvelun televisiossa informoiva ohjelmapolitiikka kytkeytyi 1960-luvun lopulla ja 1970-luvulla yhteiskunnalliseen ilmapiiriin. Samaan aikaan myös fiktiivinen televisioviihde politisoitui. Suomessa Yleisradion odotettiin osallistuvan hyvinvointivaltion ja modernin yhteiskunnan rakentamiseen yhteiskunnallista tietoa tarjoamalla (Ruoho 2001, 225).

Brittiläinen mediatutkija Laurel Forster kutsuu 1970-lukua television itsetietoisuuden saavuttamisen vuosikymmeneksi (Forster 2011). Tuolloin tehtiin tärkeä oivallus siitä, että televisiolla on suuri vaikutus niin yleiseen mielipiteeseen kuin toisaalta siihenkin, miten yleisö tarkastelee yksilöinä maailmaa television kautta. Televisiodraamasarja säilyi keskeisenä ohjelmamuotona, ja Forsterin mukaan se osoittautui hedelmälliseksi forumiksi yhteiskunnallisten aiheiden käsittelylle. Televisiokomediassa taas viitattiin ajankohtaisiin ilmiöihin ja ennen kaikkea kamppailuihin esimerkiksi aviopuolisojen tai työnantajien ja työntekijöiden välillä. Sarjat antoivat tilaisuuden nauraa toisille, itselle, instituutioille ja luokkayhteiskunnalle. Forster luonnehtii vuosikymmentä aikakautena, jolloin niin julkisessa keskustelussa kuin julkisuudessa ylipäätäänkin ideologiat, kuten marxilaisuus, feminismi ja ekologia, tulivat uudella tavalla ihmisten tietoisuuteen ja haastamaan perinteisiä yhteiskunnallisia instituutioita, kuten avioliittoa (Forster 2011, 86-87).

Ideologia ei liity television kohdalla oikeastaan sen sisältöihin tai ideajärjestelmiin kuvina ja ääninä vaan enemmänkin niihin sääntöjärjestelmiin, jotka jäsentävät ideoita, kuvia ja ääniä. Televisiotekstien maailma on täten tavallaan arkijärjen maailma ja otetaan siksi pitkälti annettuna. (Abercrombie 1996, 32.) Ideologia jäsentyy arkisen kuvauksen kautta etenkin juuri televisiofiktiossa. Esimerkiksi suomalaisessa televisiofiktiossa tarinoita on kerrottu ensi sijassa perheiden kautta, jolloin sarjojen poliittisia keskusteluja on käyty arkisesti kotona ja perheyrityksissä (Ruoho 2001, 164-165). Heikin ja Kaijan (Tamvisio/ TV2 1961-1971) nuoripari tuttavineen ja Rintamäkeläisten (TV2 1972-1978) vennamolainen Antti Rintamäki ja naapurin demari Veikko Honkonen keskustelevat politiikasta kahvipöydän äärellä. 
1980-lukua on puolestaan luonnehdittu poliittisen yksilöitymisen aloittavaksi vuosikymmeneksi. Tämä näkyi myös suomalaisessa televisiossa selkeän puoluepoliittisuuden ja asenteellisuuden vähenemisenä. (Hokka 2014, 241242.) 1990-luvun yhteiskunnallisia muutoksia käsiteltiin kuitenkin jälleen suomalaisten televisioperheiden kokemusten kautta. Esimerkiksi Metsolat (TV2 1993-1995) puhutteli lama-ajan ja Euroopan Unioniin liittymisen kynnyksellä. Perhesarjoissa yksilöiden suhteet ja vaikeudet nousivat uudelleen keskiöön 2000-luvulle tultaessa. Uuden päivän (TV2 2010-) ja Salattujen elämien (MTV3 1999-) kahvipöydissä puhutaan enemmän ihmissuhdesotkuista kuin päivän politiikasta. Poliittisuus keskittyy nykyään pääasiassa muihin lajityyppeihin, kuten asiaohjelmiin ja poliittisiin satiireihin. Poikkeuksiakin toki on, minkä esimerkiksi Pelkovaara (YLE, 2004) ja Tellus (YLE, 2014) osoittavat.

Pelkovaarassa ja Telluksessa poliittisuus on leimallisesti kansalaisaktivismia. Siinä missä Tellus on pitkälti rikosdraama, Pelkovaarassa poliittisuutta kevennetään komediallisin elementein. Ehkä yksi syy tähän on, että Telluksessa aktivistien hyökkäysten kohde on globaali markkinatalous, kun taas Pelkovaara kommentoi Suomea konkreettisesti koskevaa asiaa eli kysymystä Suomen Nato-jäsenyydestä. Voi olettaa, että aiheen kansallisesti tulenherkkä luonne vaikutti sarjan tyylilajin valintaan. Joka tapauksessa konservatismia suoranaisesti promotoiva länsimainen televisiofiktio on nykyään epätodennäköistä.

Konservatismin käsittely yleisesti on silti jälleen ajankohtaista, kun konservatiiviset arvot ovat nousseet selkeästi pintaan nykyisissä niin suomalaisissa kuin kansainvälisissä politiikan suuntauksissa ja niihin liittyvissä poliittisissa keskusteluissa. Tämän numeron tutkimusartikkelit pohtivat historiallisten esimerkkien avulla, mitä konservatiivisuus oikeastaan tarkoittaa tai pitää sisällään. Artikkeleita yhdistää myös epätavallinen näkökulma, sillä molemmat käsittelevät tilannekomediaa.

\section{Tilannekomediallinen konservatiivisuus}

Oscar Winbergin artikkeli käsittelee konservatismia amerikkalaisen television 1960-luvun lopun ja 1970-luvun alun kontekstissa. Perhe on pahin -tilannekomediasarjan (All in the Family, CBS 1971-1979) Archie Bunker (Carroll O'Connor) mielletään arkkikonservatiiviksi. Winberg kuitenkin problematisoi kyseistä mielikuvaa analysoimalla Bunkerin poliittisia mielipiteitä ja osoittaa hänen edustavan ennen kaikkea niin sanottua "konservatiivista hiljaista enemmistöä". Winbergin artikkeli avaa historiallisesti kontekstualisoituja näkökulmia konservatismin määrittelyyn, 1960-luvun lopun ja 1970-luvun alkupuolen amerikkalaiseen televisiotuotantoon ja politiikkaan. Winberg toteaa, että sarjan poliittisuus ei erityisesti kiinnostanut televisiojohtajia. Paremminkin he olivat kiinnostuneita kohderyhmien tavoittamisesta. Epäilemättä suurin ambivalenssi liittyy konservatismin lähes tiedostamattomaan liittämiseen porvarilliseen tai oikeistolaiseen maailmankuvaan. Bunker on kuitenkin ylpeä ammattiliittomies, joka kritisoi vasemmistolaista vävypoikaansa sosiaalisten velvoitteidensa laiminlyömisestä. Näin myös sukupolvikysymys nousee tärkeäksi elementiksi konservatismin ymmärtämisessä.

Rami Mähkän artikkeli tarkastelee toista klassikkoaseman saavuttanutta tilannekomediaa Pitkän Jussin majatalo (Fawlty Towers, BBC 1975, 1979). Englantilainen hotellinomistaja ja -johtaja Basil Fawlty (John Cleese) on keskiluokkainen konservatiivi, jonka mielestä Britanniasta on hävinnyt tehokkuus, ryhti ja arvokkuus, jotka kerran tekivät siitä suurta osaa maailmaa hallitsevan 
imperiumin. Artikkelin keskeisenä kysymyksenä on, miten Fawlty auttaa ymmärtämään niitä yhteiskunnallisia ja poliittisia kehityskulkuja, joiden seurauksena Margaret Thatcher valittiin Britannian pääministeriksi vuonna 1979. Mähkä väittää, että Fawlty on "esithatcherilainen" konservatiivi, joka olisi - monien brittien tavoin - jonkin aikaa epäröityään äänestänyt Thatcheria. Ironiaa asetelmaan tuo, että Fawlty edustaa itse sellaista konservatiivisuutta, jonka Thatcher näki yhtenä syynä Britannian ongelmiin.

Molemmat artikkelit tarkastelevat konservatismia ja konservatiivisuutta komedian kontekstissa. Tämä aiheuttaa väistämättä lisäkysymyksiä, sillä komedia viittaa aina ensi sijassa itseensä eli komediallisuuteen. Toisaalta se viittaa aina johonkin "vakavaan" eli ei-komedialliseen. Tässä piilee komedian merkitysten tuottamisen ainutlaatuisuus - sen yhteiskunnallinen kritiikki on erilaista kuin muiden moodien. Lisäksi, vaikka sekä Bunker että Fawlty ovat selvästi ohjelmiensa naurun kohteina, laatukomedialle on tyypillistä vaihteleva positio. Niinpä myös heidän diegeettiset (ja samalla implisiittiset ei-diegeettiset) vastapoolinsa joutuvat komediallisen kritiikin kohteeksi.

\section{Thatcher ja Trump konservatismia edustamassa}

Vuonna 2013 kuollut Margaret Thatcher oli ja on yhä edelleen monille keskeinen konservatiivisuuden ja uusliberalismin yhdistelmän edustaja, ja täysin syystä. Yhtenä merkkinä konservatismin paluusta onkin Thatcherin viime vuosien "rehabilitointi". Thatcherista ei ainakaan Britannian ulkopuolella juuri keskusteltu julkisuudessa pariin vuosikymmeneen hänen pääministeriytensä päätyttyä vuonna 1990. On selvää, että hänen nimensä mainitseminen positiivisessa asiayhteydessä saa monet takajaloilleen. Valtiovarainministeri Alexander Stubb totesi helmikuussa 2016 hallituksen yhteiskuntasopimuskamppailun jatkuessa ammattijärjestöjen kanssa, että "sydän huutaa Thatcherin ja [Elina] Lepomäen linjalle"; Thatcherhan tuli tunnetuksi taisteluistaan ammattiliittojen kanssa. Viime vuosina Thatcheria ja thatcherismia ovat kehuneet ja Suomen ongelmien ratkaisuksi tarjonneet myös muun muassa entinen taistolainen, sittemmin huippuliikemies Björn Wahlroos sekä varsinkin Aamulehden pitkäaikainen päätoimittaja, nykyinen EVA:n johtaja Matti Apunen. On syytä painottaa, että näitä avauksia tehtiin jo selvästi ennen, kuin kuolema teki Thatcherista ajankohtaisen henkilön huhtikuussa 2013.

Thatcher, thatcherismi ja niiden perintö on kuitenkin talouspolitiikkaa paljon laajempi kokonaisuus, kuten Kari Kallioniemen katsauksessa käy ilmi. Kallioniemi lähestyy Thatcheria poikkeuksellisesta näkökulmasta eli populaarikulttuurista käsin. Hän analysoi kolmea viime vuosina tuotettua elokuvaa - Rautarouva (The Iron Lady, Phyllida Lloyd, 2011), My Life with Liberace: Behind the Candelabra (Steven Soderbergh, 2013) ja dokumentti Soul Boys of the Western World (George Hencken, 2014) - thatcherismin moniulotteisuuden osoituksina. Niinpä Thatcher on yhdessä elokuvassa Meryl Streepin esittämä "drag queen", jonka ajattelun konservatiivisimmat puolet sivuutetaan tyystin. Toisaalla hän on homoseksuaalisuuden vastaisista toimistaan huolimatta nuorten konservatiivihomomiesten queer-ikoni. Tässä näkyy, miten pula-aikana kasvanut englantilainen konservatiivipoliitikko voi angloamerikkalaisen taloudellisen yksilöllisyyden ajatuksen kautta päätyä edustamaan yksilönvapautta ylipäätään.

Kimmo Ahosen näkökulmateksti tarkastelee Yhdysvaltojen tulevien presidentinvaalien kohuehdokasta Donald Trumpia amerikkalaisen konservatis- 
min taustaa vasten. Trumpin häikäilemätön mediaspektaakkeli käyttää hyväkseen suurten massojen perinteistä epäluuloa älymystöä kohtaan. Trumpin uskomattomilta tuntuvat lausunnot ovat paikoin johtaneet "friikkisirkukseen", jossa toisaalta muut konservatiiviehdokkaat ovat joutuneet kilpailemaan Trumpin populismin kanssa, toisaalta muiden puolueiden ehdokkaat on asetettu normaaliakin räikeämmin vastakohdiksi. Bernie Saundersia on muun muassa nimitetty "sosialistiksi", mikä on erityisen kiinnostavaa, kun ottaa huomioon, että Yhdysvalloissa sanalla on aivan eri kaiku kuin Euroopassa. Ahonen toteaa tekstissään, että Yhdysvaltain presidentinvaaleista on tullut todellisuudesta irtautunut ja itseään ruokkiva mediashow.

\section{Uusien tulkintojen välttämättömyys}

Tutkimuksessa pyritään uusiin innovaatioihin ja tulkintoihin, jotka lisäävät tietoamme ja ymmärrystämme maailmasta. Maiju Kanniston katsauksessa tarkastellaan uusia digitaalisia tekstilouhinnan työkaluja ja niiden avaamia merkittäviä mahdollisuuksia televisiotutkimuksessa. Kannisto nostaa esiin, miten topic modelingissa algoritmit yhdistelevät asioita, joita perinteisellä aineiston lähiluvulla ei nouse esiin. Uusilla työkaluilla on kuitenkin myös rajoituksensa, jotka tulee huomioida kriittisesti. On syytä painottaa, että tutkimusmenetelmät ovat työkaluja, eivät itse tarkoitus. Kuitenkin uusissa menetelmissä on uuden löytämisen mahdollisuus.

Sama koskee perinteisten metodien soveltamista uusiin, mahdollisesti tieteidenvälisiin kysymyksenasetteluihin. Tämän Lähikuvan numeron tavoitteena on uusien tulkintojen tekeminen jo pitkään olemassa olleesta: konservatismista poliittis-ideologisena orientaationa maailmaan. Oleellista on ymmärtää, että traditioista huolimatta ideologiat ovat historiallisen muutoksen alaisia. Siksi myös niiden tulkitseminen ja täten ymmärtäminen edellyttävät päivittämistä. Viimeistään Suomen synkät näkymät koulutuksen tulevaisuuden suhteen haastavat meidät etsimään ja tarjoamaan uutta tietoa yhteiskuntamme käyttöön.

Turussa, huhtikuussa 2016

Rami Mähkä ja Maiju Kannisto

\section{Tervetuloa digitaalisen Lähikuvan lukijaksi!}

Vuoden 2016 ensimmäinen Lähikuvan numero edustaa käännettä lehden historiassa - numero julkaistaan digitaalisena verkkolehtenä painetun lehden sijasta. Digitaalinen kulttuuri on kasvattanut merkitystään 1990-luvulta alkaen. 2000-luvulla kulttuuri on aina elokuvista musiikkiin, televisiosta pelimaailmaan, ja lehdistöstä kirjallisuuteen siirtynyt yhä enemmän digitaaliseen muotoon. Digitaalinen kulttuuri on usein helposti saavutettavissa, sillä sisällöillä on mahdollisuus ylittää maantieteellisiä rajoja, löytää uusia yleisöjä ja luoda uudenlaisia yhteisöjä. Lähikuvan toimituskin on nähnyt uudessa julkaisumuodossa monia mahdollisuuksia: avoimesti julkaistavillla teksteillä tavoitellaan näkyvyyttä ja kotimaisen audiovisuaalisen kulttuurin tutkimuksen vaikuttavuuden korostamista. 
Digitaaliseen kulttuuriin liittyy myös haasteita. Näkyvyyden saaminen verkkomaailmassa on kilpailtua. Miten taata, että Lähikuva päätyy lukijoidensa käsiin nyt, kun postinjakaja ei tiputakaan sitä enemmän tai vähemmän säännöllisesti postiluukusta? Miten saada lukijat ja kirjoittajat kohtamaan toisensa monien muiden lehtien, sivustojen ja materiaalien joukossa? Luotamme vahvaan sisältöömme, mutta joudumme miettimään myös aivan uudenlaisia viestinnän kanavia ja lukijayhteisön luomista. Tässä työssä entistä tärkeämpänä näemme yhteistyötahomme: Suomen Elokuvatutkimuksen Seuran, Turun elokuvakerhon, Varsinais-Suomen Elokuvakeskuksen, Turun yliopiston mediatutkimuksen oppiaineen ja kotimaiset yliopistot, joissa tehdään audiovisuaalisen kulttuurin tutkimusta. Yhteistyön tavoitteena on luoda yhteinen keskustelualusta, jossa eri puolilla maata ja maailmaa olevat suomenkieliset tutkijat voivat kokoontua keskustelemaan uusimmasta tutkimuksesta.

Tiedekustantamisen taloudelliset muutokset ovat vaikuttaneet Lähikuvankin uudistumiseen. Verkkojulkaisemisen suunnittelua värittivät monesti kaipuu vanhaan, uuden etsintä ja samalla uuteen varauksellisesti suhtautuminen. Onkin osuvaa, että ensimmäinen verkkonumero käsittelee uusliberalismin ja uuskonservatismin kysymyksiä. Näissäkin keskusteluissa korostuvat kamppailu uudistuksista - muutoksen etsinnästä muutosvastaisuuteen - ja markkinatalouspainottuneisuuden näkyminen. Huolimatta aavistuksen ironisesta suhtautumisesta teemojen päällekkäisyyteen Lähikuvan päätoimittajana haluan keskittyä niihin mahdollisuuksiin, joita uusi julkaisumuoto meille antaa.

Digitaalisessa muodossa sivujen painokustannukset eivät sido meitä entiseen tapaan, joten voimme julkaista useammanlaisia tekstimuotoja. Pääpaino tulee edelleen olemaan vertaisarvioiduissa tutkimusartikkeleissa, mutta haluamme tarjota myös alustan ajankohtaiseen keskusteluun näkökulmatekstien, haastatteluiden, kirja-arvioiden ja katsausten kautta. Tavoitteena on myös osallistua julkaisualustan kehitykseen siten, että yhä monipuolisempien aineistojen julkaiseminen tulisi osaksi lehden tulevaisuutta. Näin alkuvaiheissa uusi julkaisupohja ei vielä mahdollista liikkuvaa kuvaa, mutta toiveissa on, että tulevaisuudessa alustan tekniset ulottuvuudet avaisivat uudenlaista visuaalista ilmettä ja intertekstuaalista asennetta tutkimustulosten julkaisemiseen. Otammekin mielellämme kehitysideoita vastaan lukijoiltamme. Tervetuloa mukaan matkalle uudenmuotoiseen julkaisemiseen!

Helsingissä, huhtikuussa 2016

Outi Hakola

\section{Lähteet}

Abercrombie, Nicholas (1996) Television and Society. Cambridge: Polity Press.

Apunen, Matti (6.5.2014) "Kokoomuksen hyvä muistaa Thatcherin neuvot: Keskellä tietä on vaarallisinta", <http://www.hs.fi/paakirjoitukset/a1399263833489> (linkki tarkistettu 20.3.2016).

Forster, Laurel (2011) "1970s Television: A Self-Conscious Decade”. Teoksessa Sue Harper ja Justin Smith (toim.) British Film Culture of the 1970s: The Boundaries of Pleasure. Edinburgh: Edinburgh University Press.

Hokka, Jenni (2014) Kakkoselta kaikelle kansalle. Kuulumisen politiikka YLE TV2:n arkirealistisissa sarjoissa. Tampere: Tampere University Press.

"Kokoomus taipui paikallisessa sopimisessa - Stubb lähipiirilleen: Sydän huutaa Thatcherin linjalle", <http://yle.fi/uutiset/kokoomus_taipui_paikallisessa_sopimisessa_stubb_ lahipiirilleen_sydan_huutaa_thatcherin_linjalle/8701162> (linkki tarkistettu 20.3.2016). 
Luoma-Aho, Mika (2012) "Mitä totuuden jälkeen - Ajatuksia konservatismista maallistuneessa yhteiskunnassa". Niin E näin vol. 75:4, 52-58.

Ruoho, Iiris (2001) Utility Drama. Making of and Talking about the Serial Drama in Finland. Tampere: Tampere University Press.

Syrjämäki, Sami (2012) "Ideologioilla vai ilman". Niin \& näin vol. 75:4, $20-22$.

Vares, Vesa (2012) "Kahden sukulais-ismin rajamailla. Liberalismista ja konservatismista neoliberalismiin ja neokonservatismiin". Niin $\mathcal{E}$ näin vol. 75:4, 24-40.

"Wahlroos nostaisi Suomen Thatcherin opeilla", <http://yle.fi/uutiset/wahlroos_nostaisi_ suomen_thatcherin_opeilla/5914373> (linkki tarkistettu 21.3.2016).

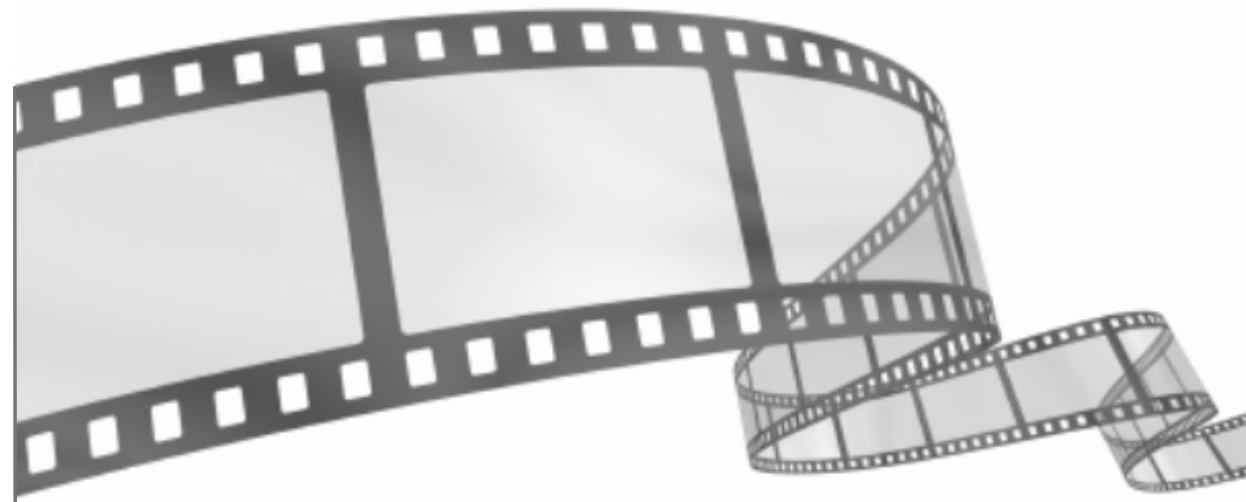

\section{SUOMEN ELOKUVATUTKIMUKSEN SEURAN SEMINAARI 4.11.2016}

Suomen elokuvatutkimuksen seura järjestää perinteisen vuosiseminaarin elokuvan ja audiovisuaalisen median tutkijoille Helsingissä Tieteiden talolla perjantaina 4.11.2016.

Ohjelmassa on ajankohtaiseen tutkimukseen tutustumista, materiaaliesittelyjä, keskusteluja ja verkostoitumista. Mukaan ovat tervetulleita kaikki elokuvaa, televisiota, pelejä, av-mediaa tai niihin liittyviä aiheita tutkivat ja tutkimuksesta kiinnostuneet - niin graduntekijät, väitöskirjantekijät kuin väitelleetkin.

Osallistujia pyydetään valmistelemaan lyhyt esitys (n. 20 min) omasta tutkimusaiheestaan. Esitelmien maksimipituus ja aikataulu varmistuvat, kun tiedetään osallistujamäärä. Tilaisuuteen voi osallistua myös ilman esitystä.

Seminaarin jälkeen pidetään Suomen Elokuvatutkimuksen seuran syyskokous. Päivän päätteeksi on varattu mahdollisuus jatkaa keskustelua ja viettää iltaa.

ILMOITTAUDU ESITELMÄN PITÄJÄKSI 30.9.2016 MENNESSÄ elokuvatutkimuksen.seura@gmail.com

Kerro ilmoittautuessasi nimesi, yhteystietosi, organisaatiosi (esim. yliopisto/oppiaine) ja esityksesi alustava otsikko.

TERVETULOA! 